\title{
当科における超高齢者の頝椎手術の術後成績
}

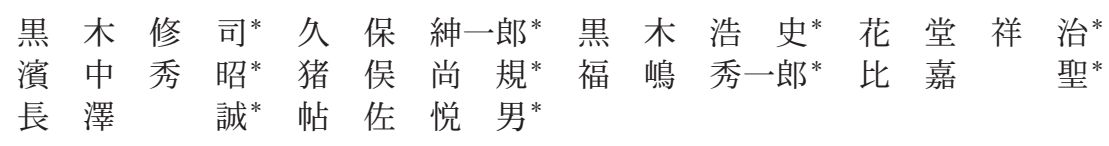

\section{Results of Surgical Treatment of Cervical Spine in the Oldest-old}

Shuji Kurogi*, Shinichiro Kubo*, Hiroshi Kurogi*, Shoji Hanado*, Hideaki Hamanaka*, Naoki Inomata*, Shuichiro Fukushima*, Kiyoshi Higa*, Makoto Nagasawa*, and Estuo Chosa*

近年, 高齢者手術は増加傾向にあり，当院においても同様の傾向を認める. 今回われわれは当科におけ る超高齢者（85 歳以上）の頚椎手術症例の術後成績を検討したので報告する。対象は 2004 年 1 月より 2009 年 9 月まで当科にて施行した 85 歳以上の頝椎椎弓形成手術 9 例, 男性 5 名女性 4 名, 平均年齢は 87.4 歳である. 術前診断は頚椎症性脊髄症 8 例, 後縦勒带骨化症 1 例であった. 日本整形外科学会頸髄 症治療成績判定基準（以下 JOA score）の平均値は術前 8.8 から最終観察時 12.9 と改善を認め, 全ての 症例で麻痺の悪化や予後不良となる重大な術後合併症を認めなかつた. 超高齢者であつても術前の評価と 適応を十分検討すれば，観血的治療は有用な治療法と考える.

In recent years, the number of geriatric operations is on the increase, and a similar tendency is seen at our center. This time, we reviewed the results of surgical treatment of the cervical spine in the oldest old (over 85 years old) and report our findings in the following.

Subject of research: Nine cases (five males and four females) over 85 years old who underwent cervical laminoplasty at our center from January 2004 to September 2009. Their mean age was 87.4 years. Preoperative diagnosis was eight cases of cervical spondylomyelopaty and one case of ossification of the posterior longitudinal ligament.

The mean score of the Japan Orthopaedic Association improved from 8.8 (before operation) to 12.9 (in the last clinical evaluation). There are no cases of evolving paralysis and severe complications after surgery.

Invasive treatment for the oldest old is useful with sufficient preoperative evaluation and examination of the operative indicators.

Key words : oldest old (超高齢者), surgical treatment of cervical spine (頝椎手術), Japan Orthopaedic Association Score（日本整形外科学会頸髄症治療成績判定基準）

$$
\text { は じめに }
$$

近年，高齢者手術は増加傾向にあり，当院において も同様の傾向を認める. 今回われわれは当科における 85 歳以上の超高齢者の頚椎手術症例の術後成績を検 討したので若干の文献的考察を加えて報告する.
対象と方法

超高齢者群は 2003 年より 2009 年 9 月まで当科にて 施行した 85 歳以上の頸椎椎弓形成術症例, 男性 5 名 女性 4 名で平均年齢は 87.4 歳である.

比較対象群として 2008 年に当科にて施行した頸椎 椎弓形成術症例で 75 歳から 84 歳までの後期高齢者群 9 例, 65 歳から 74 歳までの前期高齢者群 12 例, 64

\footnotetext{
* 宮崎大学整形外科 Department of Orthopaedic Surgery, Miyazaki University School of Medicine, Miyazaki, Japan
} 
歳以下の中年者群 15 例とした.

検討項目は JOA スコアの術前後での変化，手術時 間, 出血量, 術後せん妄出現の有無, 精神科受診の有 無，その他の術後合併症で，危険率 $5 \%$ で各項目の 検討を行った.

結果

当科での年齢別の頸椎手術数の推移を示す（図 $1 \mathrm{a}$ ). 2009 年は 9 月までの症例数である. 中年者群は全頸 椎手術症例のおおよそ $50 \%$ を占め，前期高齢者群が
$26 \%$ 後期高齢者群が $23 \%$ と年齢とともに全頸椎手術 に占める割合が低下していた.

超高齢者の頸椎手術は全頸椎手術症例の $2.4 \%$ と少 ないが, 2006 年より徐々に増加傾向を認めている.

次に年齢別の全脊椎手術に占める頸椎手術の割合を 検討した（図 $1 \mathrm{~b}$ ).

中年者群・前/後期高齢者群では，それぞれ全春椎 手術の約 3 割が頸椎手術であるのに対し，超高齢者群 では 2006 年以降頚椎手術の割合が漸増し, 近年はそ のほとんどが頸椎手術であった。

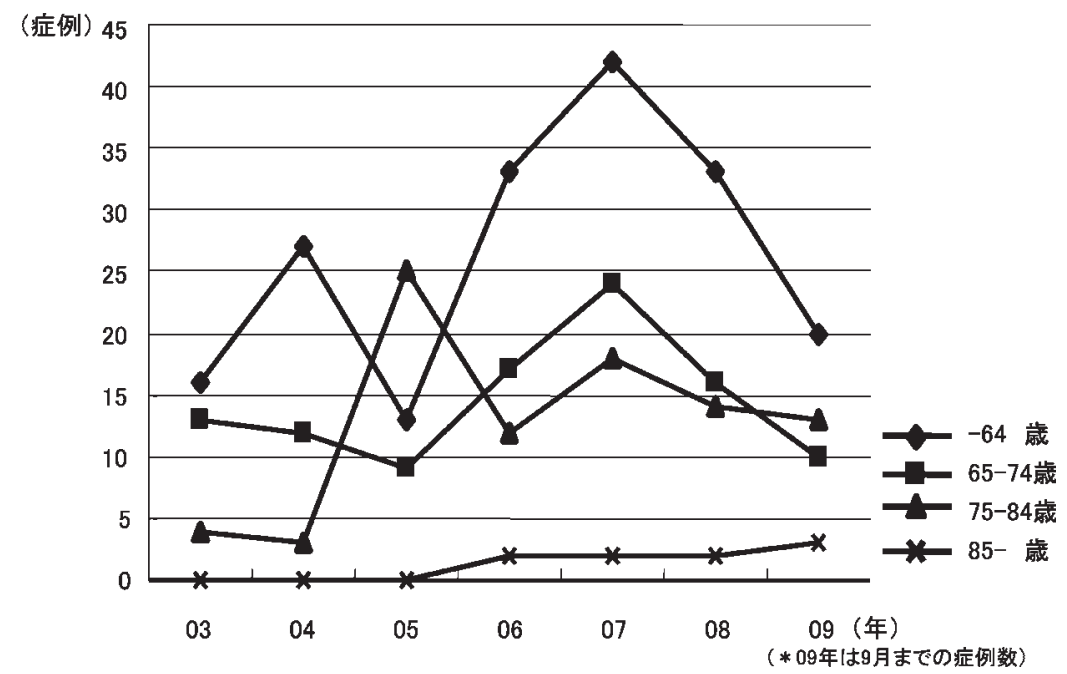

図 $1 \mathrm{a}$ 当科での年齢別の頝椎手術症例数の推移

(\%)

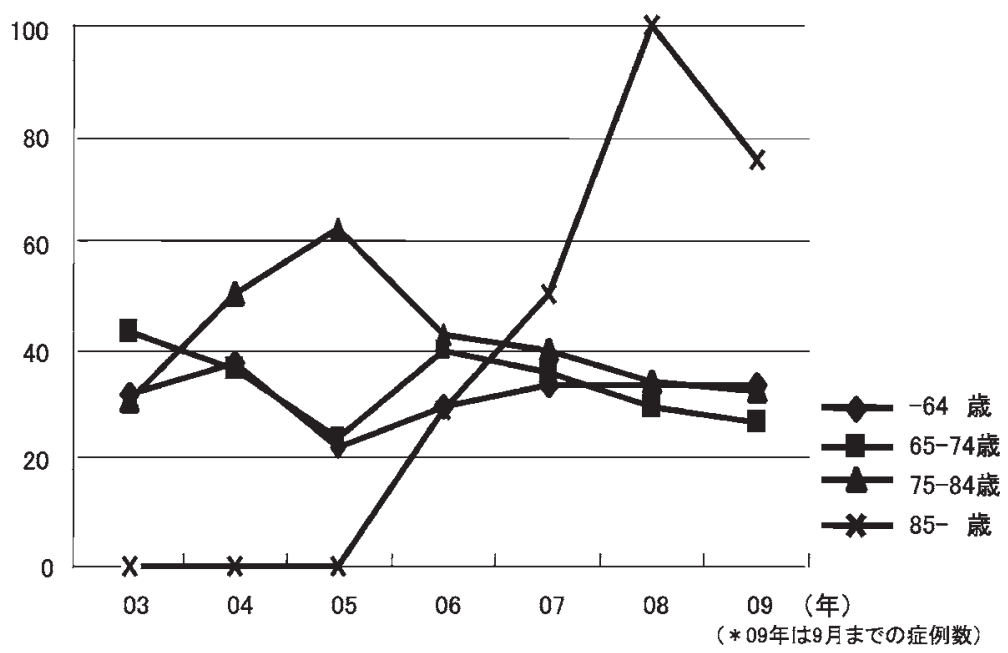

図 $1 \mathrm{~b}$ 当科での年齢別の全脊椎手術に占める頚椎手術割合の推移 
超高齢者群・前後期高齢者群・中年者群の各群での JOA スコアの術前後での変化を示す（図 2). 各群で 術前後での JOA スコアは有意に改善を示し, 改善率 も超高齢者群で $47.2 \%$, 後期高齢者群で $48.5 \%$, 前 期高齢者群で $51.2 \%$ ，中年者群で $58.9 \%$ と改善率で 各群に有意差を認めなかったが, 年齢とともに低くな る傾向を示した.
また超高齢者群の術前 JOA スコアは後期高齢者群 と比べ低い傾向を認め, 前期高齢者群や中年者群と比 ベ有意に低く，超高齢者では特に手術適応を厳しく判 断していることが示唆された.

手術時間や出血量, ドレーン抜去までの日数を検討 し，各群で特に有意差を認めなかった（表 $1 \mathrm{a} ）$.

次に術後不穏症例や精神科受診の有無, 術後合併症

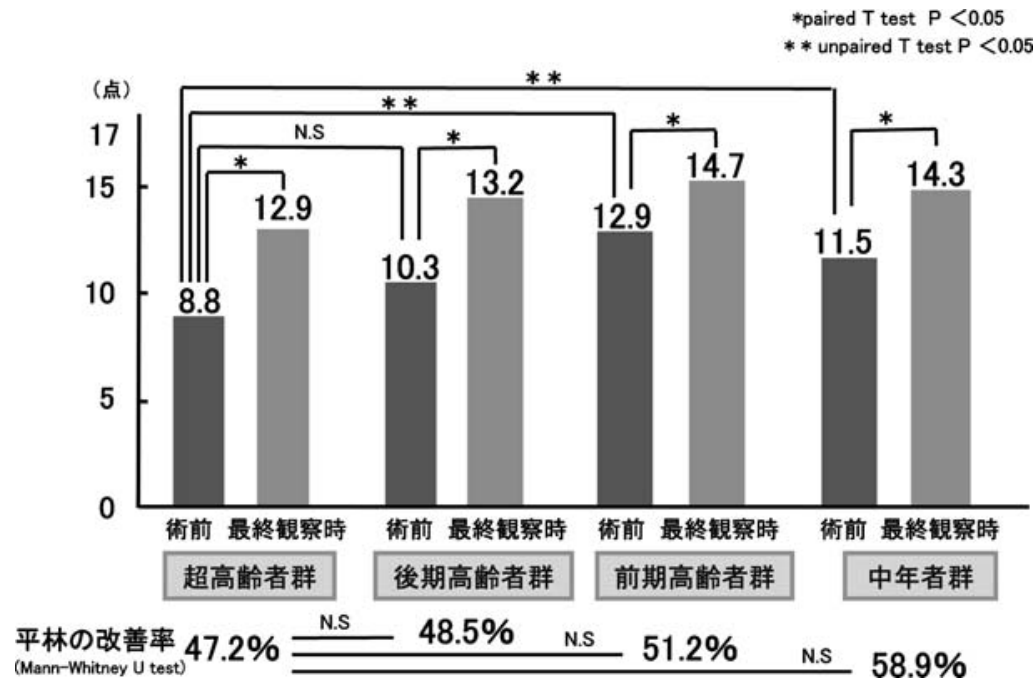

図 2 各群での JOA スコアの術前後での変化および改善率

表 1 a 手術時間・出血量・ドレーン抜去までの日数に有意差を認めなかつた

\begin{tabular}{|c|c|c|c|c|c|c|c|}
\hline & 超高齢者 & & 後期高齢者 & & 前期高齢者 & & 中年者 \\
\hline 症例数 & 9 & & 9 & & 12 & & 14 \\
\hline 手術時間 & 184 & N.S & $\stackrel{173}{\longleftarrow}$ & N.S & 172 & N.S & $\stackrel{181}{+}$ \\
\hline 出血量 & 141 & N.S & $\stackrel{100}{\longrightarrow}$ & N.S & $\begin{array}{c}84 \\
\downarrow\end{array}$ & N.S & $\begin{array}{c}139 \\
+\end{array}$ \\
\hline $\begin{array}{l}\text { ドレーン抜去 } \\
\text { までの日数 }\end{array}$ & 2.44 & N.S & 2.90 & N.S & $\stackrel{2.83}{\rfloor}$ & N.S & 2.43 \\
\hline
\end{tabular}

表 $1 \mathrm{~b}$ 術後不穏症例数超高齢者群と中年者群で有意差を認めた

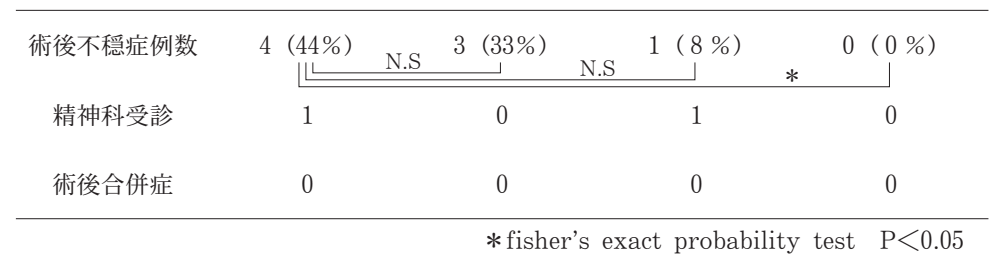




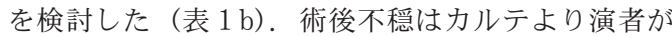
術後に不穏と判断する言動や行動の記載があったもの を検討した.

術後不穏は超高齢者群と中年者群間のみ有意差を示 したが，各群で年齢とともに不穏の発症が増大する傾 向であった。一方精神科受診するほどの症例は少なく 数日の経過観察のみで軽快する症例がほとんどであっ た. また不穏以外の術後の重大な合併症の発生を各群 で認めなかった。

\section{考察}

野坂ら ${ }^{5)}$ は 65 歳以上の高齢者脊椎手術において頚 髄症によるものが $23 \%$ を占めたと報告し, 田中ら” も 75 歳以上の高齢者脊椎手術において頚䯣症による ものが $31 \%$ を占めたと報告している．今回当科では 65 歳以上の全春椎手術において頝䯣症は $35 \%$ を占め, 前者らの報告に比べ頸䯣症の占める割合が高い傾向を 示した．また超高齢者群で 2006 年以降全脊椎手術に 占める頝椎手術の割合は増加傾向を示しており, 中年 者群・前後期高齢者群と比べ高い傾向であった，手術 による合併症発症のリスクが高いなかで春䯣障害によ る ADL 低下に対し頸椎手術を行っていることが考え られた. Matsuda ら²) は 75 歳以上の高齢者の頝椎手 術で JOA スコアの改善率が $39.1 \%$ であったと報告し, また田中ら ${ }^{6)}$ は 80 歳以上の䅡椎手術において $36.6 \%$, Nagano ら ${ }^{3)}$ も $35 \%$ の JOA スコアの改善率であった と報告している.

当科では今回, 超高齢者群の頝椎手術において 47.3\% と他文献と比較して良好な JOA スコアの改善 率を示した．前後期高齢者群や中年群と比較し有意差 を認めないが年齢とともに JOA スコアの改善率が低 下する傾向であった.

中瀬ら ${ }^{4)}$ は, 70 歳以上の高齢者脊椎手術後に $19.1 \%$
の不穏症状が見られたと報告し，石原ら ${ }^{11}$ も 80 歳以 上の高齢者脊椎手術後の $23.1 \%$ に不穏症状が見られ たと報告した.

当科でも超高齢者の $44 \%$, 後期高齢者の $33 \%$ に術 後不穏が認められた，超高齢者群で不穏以外の術後合 併症を認めなかった。術後不穏の発症は年齢とともに 増加傾向を認め, ドレーン抜去時期や, 術後安静度の 早期改善など周術期管理の検討が必要と思われた.

結語

当科における 85 歳以上の超高齢者頝椎手術の術後 成績を報告した．超高齢者の䅡椎手術では高齢者群や 中年者群と比較し術前JOA スコアが有意に低かった が, JOA スコアの改善率や術後合併症発症に有意差 を認めず良好な成績であった，超高齢者や後期高齢者 で頝椎手術後に不穏が出現することが多い傾向を認め, 術前準備と周術期管理に注意を要すると考える.

\section{参 考 文 献}

1）石原陽平ら：高齢者（80 歳以上）に対する春椎手術の 换討．東日本整災会誌， $20 ： 210-213,2008$.

2) Matsuda, Y., et al.: Outcomes of surgical treatment for cervical myelopathy in patients more than 75 years of ages. Spine, $24: 529-534,1999$.

3) Nagano, A., et al.: Surgical treatment for cervical myelopathy in patients aged $>80$ years. Orthopedics, $27: 45-48,2004$.

4）中瀬裕之ら：高齢者に対する春椎手術．Spinal Surgery, $17(1): 23-28,2003$.

5）野坂光司ら：当科における過去 20 年間の高齢者春椎 手術の動向。日本脊䯣障害医学会雑誌，19(1)：94-95, 2006.

6) 田中裕之ら：80歳以上の高齢者に対する䅡椎椎弓形成 術. 中部整災誌, $42: 961-962,1999$.

7）田中靖久ら：超高齢者の脊椎手術。整・災外，42： 391-399, 1999. 